\title{
The Impact of Professional Development, Modern Technologies on Lecturers' Self-Efficacy: Implication for Sustainable Science Education in Developing Nations
}

\author{
David Agwu Udu*, Benson Ikechukwu Igboanugo, John Nmadu, Chidebe \\ Chijioke Uwaleke, Benjamin Chukwunonso Okechineke, Adaora Phina \\ Anudu, Precious Chisom Attamah, David Onyemaechi Ekeh \\ and Mercy Ifunanya Ani \\ Alex Ekwueme Federal University, Ndufu-Alike, Ebonyi State, Nigeria \\ https:// orcid.org/0000-0003-3632-8190 \\ https://orcid.org/0000-0002-5913-317X \\ https://orcid.org/0000-0002-1787-9491 \\ https://orcid.org/0000-0003-4504-6064 \\ https://orcid.org/0000-0002-2806-6146 \\ https://orcid.org/0000-0002-8704-5716 \\ https://orcid.org/0000-0002-4670-7576 \\ https://orcid.org/0000-0002-8247-2460 \\ https://orcid.org/0000-0002-0776-3882
}

\begin{abstract}
This study evaluated the impact of a professional development program (PDP) on science lecturers' level of knowledge/understanding and the extent of use of modern technologies for improving their self-efficacy in teaching in the areas of students' engagement, instructional strategies, and classroom management, in some selected universities in Nigeria. The study adopted a descriptive survey design. The sample was 269 lecturers. The researchers adapted the teacher sense of efficacy scale (TSES) developed by Tschannen-Moran and Hoy (2001) for the study. The TSES has two parts (1) and (2) that contained 12 questions each. It was a validated instrument, with overall reliability indices of 0.92 and 0.95 respectively determined using Cronbach's Alpha. The data obtained were analyzed with mean, standard deviation, and paired sample t-test. The study found that the PDP improved the lecturers' understanding of modern technologies and self-efficacy in teaching $\left(\mathrm{t}_{(268)}=30.959, p=0.000<\right.$ $0.05)$. Also, the PDP improved the lecturers' extent of utilisation of modern technologies and self-efficacy in teaching $\left(\mathrm{t}_{(268)}=28.510, p=.000\right.$ $<.05)$. The study also found that the lecturers' understanding of modern technologies after the PDP was high, but their use of modern technologies in teaching was still low. The researchers recommended that science lecturers' participation in PDPs should be regular to
\end{abstract}


improve their understanding and use of modern technologies in teaching for enhanced self-efficacy and sustainable science education in developing nations.

Keywords: professional development; modern technologies; selfefficacy; science lecturers; sustainable science education

\section{Introduction}

Speck and Knipe (2005) see professional development as people development and engagement activities culminating into learning to earn or maintain professional credentials in general. Speck and Knipe note that these activities are acquiring academic degrees through formal coursework, attendance at conferences, workshops, seminars, and other informal learning opportunities situated in practice in professional development programs. In the educational context, Liu (2012) defines professional development as a wide variety of specialized training, formal education, or advanced professional learning intended to help and support school administrators, teachers, and other educators to improve their professional competence, skill, and effectiveness. Similarly, the Organisation for Economic Cooperation and Development, OECD, (2009) sees professional development programs as activities that develop an individual's skills, expertise, and other characteristics.

On the other hand, Djigic, Stojiljkovic and Doskovic (2014) and Caprara et al. (2006) describe self-efficacy as an educator's belief in his ability to successfully cope with tasks, obligations, and challenges related to his/her professional roles in the educational environment. Klassen and Tze (2014) note that an understanding of educators' self-efficacy is vital to teaching effectiveness, instructional practices, and improving students' academic achievement. Some studies have proven that using modern technologies in the teaching and learning processes enhances the educator's sense of self-efficacy. Moreover, professional development programs are vital tools for assisting educators in knowledge acquisition and utilizing modern technologies in teaching and learning processes (Caprara et al., 2006, Barni et al., 2019, Udu, 2020). Tertiary institutions lecturers should be exposed to professional development programs (PDPs) regularly to enhance their knowledge and use of modern technologies in teaching. It is very vital to the enhancement of their self-efficacy and for sustainable science education programs in the developing nations, including Nigeria.

Most developing nations saw the importance of modern technologies in teaching in their tertiary institutions and have committed some funds to acquire some modern technologies. For instance, in Nigeria, many Universities have purchased some modern technological gadgets for teaching. The items were provided in the universities by the Nigerian Tertiary Education Trust Fund (TETfund) in conjunction with the Nigerian Communications Commission (NCC). Previous researchers found that many modern technological gadgets have been acquired and installed in the universities for teaching purposes, however, many lecturers do not use the gadgets in their classroom teaching and 
learning processes. The lecturers have not been successfully integrating these modern technological gadgets into their courses for effective teaching and learning processes (Hennessy, Ruthven \& Brindley, 2005, Goktaş, Yıldırım \& Yildırım, 2008, Udu, 2020). Besides, McCarney, (2004) notes that professional development programs help lecturers to learn effective ways of utilizing and integrating modern technologies into teaching, thereby achieve their self-efficacy in teaching and learning processes. Therefore, this study that evaluates the impact of professional development programs on science lecturers' knowledge and utilization of modern technologies offers a route map for enhancing their effectiveness in teaching and learning processes, thereby improving their selfefficacy for sustainable science education.

\section{Modern Technologies in Education}

Modern technology refers to the electronic tool, piece of equipment, or device that helps students to accomplish specified learning goals (Davies, Sprague \& New, 2008). Modern technologies play crucial roles in human lives and are specifically vital in the teaching and learning processes. Marshall (2010) observes that the impacts of modern technologies are felt in all fields of study, including education. Marshall notes further that effective use of technologies in education will change the face of education and create more educational opportunities. For instance, the lecturers are beginning to learn how to integrate technologies in their classrooms, while the students are getting more interested in learning with technologies (Karehka, 2013). Besides, Chen (2008) opines that teaching and learning facilities should be made available to the lecturers for effective teaching and learning, such as modern technological gadgets, ranging from low-tech equipment, like the chalkboard, to more sophisticated presentation software. These may include online collaboration and conferencing materials for effective teaching and learning processes in the universities. However, Lynch (2017) observes that modern technology may not be applied effectively in the classrooms without knowledgeable educators with the basic knowledge of the technology and its implementation to meet educational goals. Continuing, Lynch analyzed the modern technology utilization in the classrooms and likened it to a foray into modern invention in which the educator gets to be the expedition leader. Concluding Lynch infers that rather than viewing modern technologies (such as digital devices and internet spaces) as a "threat" to their duties, the educators (lecturers and teachers) should view them as unexplored areas of growth for both themselves and their learners. Besides, the United States Department of Education (2011) contributed by observing that modern technologies are potential transformers of teaching by ushering in a new model of connected wholes in teaching. This new model will be equipped and link the lecturers to their students, professional content, resources, and other systems that improve the instructional strategies and sense of efficacy. Therefore, the importance of modern technology integration in science education for effective teaching and learning processes in the universities cannot be over-emphasized.

\section{Professional Development Programs and Self-efficacy}

Padwad and Dixit (2011) see a professional development program as a planned, continuous, and lifelong process in which lecturers and other educators develop 
their personal and professional qualities, to improve their knowledge, skills, and practice0 leading to the achievement of their self-efficacy. Similarly, Kennedy (2005) and Whitcomb, Borko, and Liston (2009) reiterated that engaging the lecturers in regular professional development programs will improve their teaching quality, enhance students' achievement and improve the self-efficacy of the educators. Furthermore, engagement in professional development programs positively impacts the lecturers' ability to critically develop the knowledge and skills they require for good professional practices with their students and colleagues (Buczynski \& Hansen, 2010; Gabriel, Day \& Allington, 2011, Tareq, 2020). Besides, Fullan (2015) and Yoo (2016) emphasized that professional development programs contribute to the educators' effectiveness by providing the avenue for a continuous individual and collective enhancement of their teaching strategies, which are necessary for the overall improvement of the students' learning outcomes. Besides, Mohammad and Khaled (2017) averred that lecturers need regular opportunities to update their professional knowledge and skills. These are available in professional development programs.

Furthermore, according to Tschannen-Moran and Hoy (2001) self-efficacy is the judgment of the lecturer's/teacher's capabilities to bring about desired outcomes of students' engagement and learning. Tschannen-Moran and Hoy note further that self-efficacy can measure effectiveness in students' engagement, use of instructional strategies, and classroom management. Some research findings suggest that self-efficacy correlates positively with other constructs like selfregulated learning (Lau, Liem \& Nie, 2008), motivation and academic performance work stress (Usher \& Pajares, 2008), job satisfaction (Chong et al., 2010), and students' outcome (Moe, Pazzaglia \& Ronconi, 2010). Lecturers with a high level of sense of self-efficacy are more likely to stay in their teaching professions, spend more time teaching, make great efforts in classroom management, and show great enthusiasm for teaching. They respond to their student's needs and are willing to spend more time working with problematic students (Tschannen-Moran \& Hoy, 2001, Ho \& Hau, 2004). Lecturers with a high level of sense of self-efficacy are very valuable in the teaching profession. This study that evaluates the use of modern technologies to improve lecturers' self-efficacy through professional development programs is justified.

Meanwhile, the theoretical underpinning of lecturers' self-efficacy is directly related to the social cognitive theory of behavioral change developed by "Bandura" in 1977. Bandura's learning theory relates to the lecturer's belief in his ability to cope with tasks, obligations, and challenges in his professional role successfully (Barni et al. (2019). Caprara et al. (2006) identified the roles to include; didactical tasks, managing discipline problems in the classroom, and other issues. Based on bandura's socio-cognitive theory of behavioral change, researchers have opined that lecturers with a high level of students' engagement in the teaching and learning processes exhibit a high level of self-efficacy (Caprara et al., 2006). Similarly, when lecturers utilize several instructional strategies to drive home learning, the outcome is usually high academic achievement and a high level of self-efficacy (Djigic et al. 2014). Also, the exhibition of good managerial skills evidenced in the lecturer's effective 
classroom management gives rise to the lecturers' high self-efficacy (Sousa et al. 2012). This study, therefore, investigates how the use of a professional development program on the knowledge and use of modern technologies can improve the lecturers' self-efficacy in the teaching and learning processes in the universities.

It has been established from research studies that professional development programs are vital tools for the improvement of the lecturers' self-efficacy in the teaching and learning processes in the universities. It is expedient that lecturers should avail themselves the opportunities for active engagement of modern technologies in teaching and learning processes provided by professional development programs. It will enhance their professional proficiency and selfefficacy in the teaching and learning processes.

Meanwhile, the Advanced Digital Appreciation Programme for Tertiary Institutions (ADAPTI) is a professional development program that provides training on modern technologies in education. The ADAPTI program is a unique platform used for training the academic and non-academic staff of Nigerian tertiary institutions. The focus of the program is on the proficient use of modern technologies such as basic information and communication technology (ICT) office productivity tools, including the internet, use of e-teaching and e-learning facilities as well as collaborations in course delivery for enhanced e-teaching and learning (Digital Bridge Institute, 2018). The ADAPTI equips participants with these essential modern technological skills through hands-on training and learning approaches to translate the acquired knowledge and skills to improve teaching and research (Udu, 2018).

Several studies have shown that professional development programs increase knowledge and use of modern technologies in teaching and learning (Voogt, Almekinders, Van den Akker, \& Moonen, 2005; Lavonen et al., 2006; Giordano, 2008).

However, some studies found that the professional development program increases the educator's acquisition of modern technology skills, and the extent of usage of these modern technologies was still low (Brinkerhoff, 2006; Fragkouli \& Hammond, 2007; Glazer et al., 2009). Nevertheless, Liu (2012) supports the fact that professional development programs increase the educator's skills in modern technology usage in teaching and learning.

Based on the preceding facts, professional development programs have enhanced the lecturers' acquisition of modern technology skills for teaching, however, regular use of these technologies that enhance the lecturers' selfefficacy in teaching and learning processes were yet to be accomplished. Hence this study evaluates the relationship between professional development programs and the lecturers' knowledge and use of modern technologies for improving their self-efficacy in teaching in the areas of students' engagement, instructional strategies, and classroom management, as illustrated in figure 1. Specifically, this study evaluates the impact of PDP on the science lecturers' 
knowledge and use of modern technologies for improving their self-efficacy in teaching on the completion of the professional development program (ADAPTI).

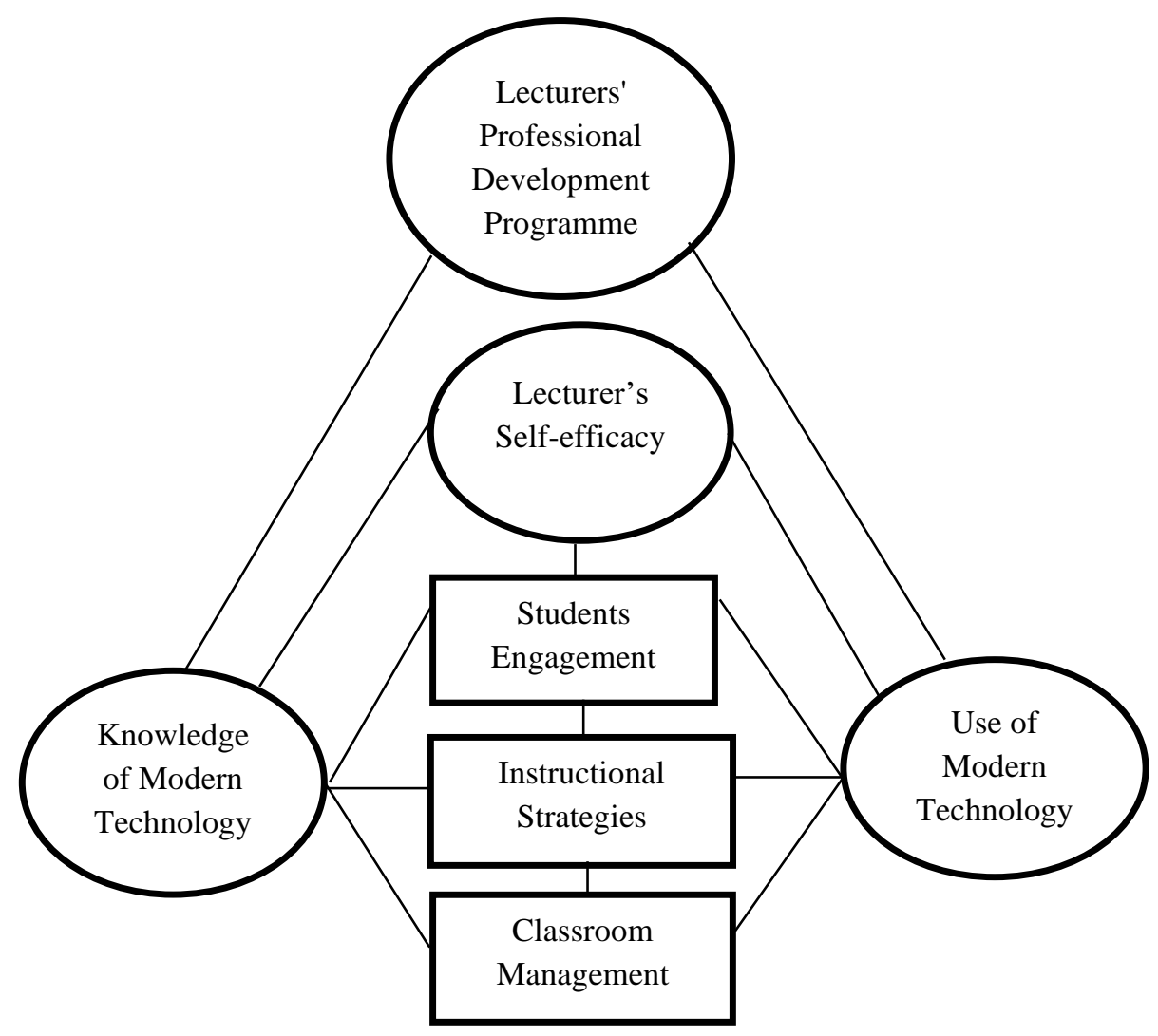

Figure 1: Model of the variables relationships of the study (Source: own elaboration)

The knowledge and use of modern technologies in teaching and learning processes acquired through professional development programs are becoming a priority to educational institutions, lecturers, and other stakeholders in developing nations, particularly, in Nigeria (Udu, 2020). It is, therefore, essential to explore how professional development programs can enhance lecturers' knowledge and use of modern technologies for improving their self-efficacy in teaching and learning processes in Nigerian universities. Specifically, this study addresses the following research questions, with corresponding hypotheses:

R1 What is the impact of PDP on the science lecturers' level of knowledge of modern technologies for improving their self-efficacy in teaching in the universities?

$\mathrm{H}_{\mathrm{o}} 1$ There is no significant impact of PDP on the science lecturers' knowledge of modern technologies for improving their self-efficacy in teaching in the universities.

R2 What is the impact of PDP on the science lecturers' use of modern technologies for improving their self-efficacy in teaching in the universities?

$\mathrm{H}_{\mathrm{o}} 2$ There is no significant impact of PDP on the science lecturers' use of modern technologies for improving their self-efficacy in teaching in the universities. 
R3 Is there any difference in the science lecturers' overall knowledge and use of modern technologies for improving their self-efficacy in teaching after completing the PDP?

$\mathrm{H}_{\mathrm{o}} 3$ There is no significant difference in the science lecturers' overall knowledge and use of modern technologies for improving their selfefficacy in teaching after completing the PDP.

\section{Method and Materials}

The study adopted a descriptive survey design. The sample was 269 science lecturers from three universities that participated in a professional development program (PDP) - the Advanced Digital Appreciation Program for Tertiary Institutions (ADAPTI) in 2018. The sample was composed of 175 (65\%) males and $94(35 \%)$ females drawn using a stratified random sampling technique. The participants indicated binary gender only. All the lecturers were full-time staff of the universities, with an age range of 33 to 55 years $(M=42, S D=6.2)$. Years of experience range from 5 to 25 years $(M=13, S D=5.6)$. The Assistant Lecturers were 94 (35\%), Lecturer II, 81 (30\%), Lecturer I, 62 (25\%), and Senior Lecturers 27 (10\%). They were biological sciences and biology education, 91 (34\%), chemistry and chemical education $86(32 \%)$, physics and physics education, $57(21 \%)$, and mathematics and related courses, $35(13 \%)$.

The "Teachers' Sense of Efficacy Scale" (TSES) developed by Tschannen-Moran and Hoy (2001) to measure the sense of efficacy for teachers was the instrument adapted for this study (Appendix 1). The TSES has two versions: a long-form (24 items) and a short form (12 items). Tschannen-Moran and Hoy (2001) indicated that both forms of the TSES were considered almost identical in their effectiveness in measuring self-efficacy because they have very similar psychometric values. Specifically, the short form/version of the TSES was the instrument adapted for this study. The short version of the TSES is composed of 12 items with three subscales which are: efficacy for student engagement (ESE), with (4) items, efficacy for instructional strategies (EIS), with (4) items, and efficacy for classroom management (ECM), with (4) items. The adapted TSES was used in the two (2) parts of the instrument. Part 1 assessed the lecturers' selfefficacy in the knowledge of modern technologies in teaching while part 2 assessed the lecturers' self-efficacy in the use of modern technologies in teaching in the areas of efficacy for students' engagement (ESE), efficacy for instructional strategies (EIS), and efficacy for classroom management (ECM). The TSES was a validated instrument with factor loadings that ranged from 0.60 to 0.85 and accounted for $61 \%$ of the variance.

Also, the construct validity that assessed its correlation with other existing scales of teaching efficacy, shows that it successfully confirms the construct of efficacy (Tschannen-Moran \& Hoy, 2001). In part 1 of the TSES, the original instrument had alpha (a) values of 0.81, 0.86, and 0.86 for the ESE, EIS, and ECM respectively, and an overall value of 0.91 . In the adapted TSES the alpha ( $\alpha$ ) values obtained were $0.81,0.86$, and 0.88 for the ESE, EIS, and ECM respectively, and an overall value of 0.92 . These values were consistent with the results of Tschannen-Moran and Hoy (2001) thereby confirm the reliability of the adapted 
instrument. Some examples of items adapted in the questionnaire for the ESE, EIS, and ECM are as given. The item "How much can you do to motivate students who show low interest in schoolwork?" was adapted as "To what extent can your knowledge of modern technologies help you to motivate students who show low interest in schoolwork?" The item "To what extent can you craft good questions for your students?" was adapted as "To what extent can your knowledge of modern technologies assist you in crafting good questions for your students?" The item "How much can you do to control disruptive behavior in the classroom?" was adapted as "To what degree can your knowledge of modern technologies help you to control students' disruptive behavior in the classroom?" Similarly, in part 2 of the TSES, the original instrument had alpha (a) values of $0.81,0.86$, and 0.86 for the ESE, EIS, and ECM respectively, with an overall value of 0.91 . In the adapted TSES the alpha values obtained are $0.79,0.86$, and 0.83 for the ESE, EIS, and ECM respectively with an overall value of 0.95 . These results were also consistent with the results obtained by Tschannen-Moran and Hoy (2001) which confirms the reliability of the adapted instrument. Some examples of items adapted in the questionnaire for the ESE, EIS, and ECM are given. The item "How much can you do to motivate students who show low interest in schoolwork?" was adapted as "To what extent do you use modern technologies to motivate students who show low interest in schoolwork?" The item "To what extent can you craft good questions for your students?" was adapted as "To what extent do you use modern technologies to craft good questions for your students?" The item "How much can you do to control disruptive behavior in the classroom?" was adapted as "To what extent do you use modern technologies to control disruptive behavior in your classroom?"

The researchers used the adapted TSES in the Pre- and Post-PDP surveys that assessed the Lecturers' knowledge and the use of modern technologies in teaching before and after completing the PDP. There were two sections, A and B in the TSES. Section A was for obtaining personal data of the respondents like age, gender, years of teaching experience, rank, department, etc., while section $B$ contained 24 questionnaire items separated into two parts, 1 and 2, as described above. The TSES has a five-point rating scale instrument that ranges from 1 (very small extent) to 5 (very large extent).

Furthermore, the survey was conducted twice, before the PDP, and eight (8) months after the PDP. The participants were informed about the study and they consented to be involved in the study. The questionnaires were distributed to the lecturers on the first day of the ADAPTI program at their various universities where the researchers visited them. Their responses were collected on the spot and also their contact details. The contact details collected enabled the researchers to reach out to them after the program for the post-survey responses. The researchers received a total of 289 fully responded and completed questionnaires in the pre-program survey. Out of a total of 297 fully responded/completed questionnaires in the post-survey, only 269 questionnaires had "matching pairs" and were the sample of the study. The 
researchers utilized the data obtained from the 269 participants who completed both the pre-surveys and post-surveys for the data analysis.

Data analyses using mean, standard deviation, and the paired sample t-test. The alpha level was set at $p<0.05$ for the t-tests. The researchers used the Statistical Package for the Social Sciences (SPSS) software version 23 for data analysis.

\section{Results}

The results are in tables according to the research questions and hypotheses. The first research question was on the impact of PDP on the science lecturers' knowledge of modern technologies for improving their self-efficacy in teaching in the universities.

Table 1: Summary of Mean and Standard deviation of Lecturers' Pre- and PostSurveys on Knowledge of Modern Technologies

\begin{tabular}{|c|c|c|c|c|c|}
\hline Item & $\mathrm{N}$ & Group & Mean & \multirow{2}{*}{$\begin{array}{c}\text { Std. } \\
\text { Deviation }\end{array}$} & \multirow{2}{*}{$\begin{array}{c}\text { Std. } \\
\text { Error } \\
\text { Mean }\end{array}$} \\
\hline $\begin{array}{l}\text { Knowledge of modern } \\
\text { technologies }\end{array}$ & & & & & \\
\hline \multirow{2}{*}{$\begin{array}{l}\text { Teacher efficacy in } \\
\text { students' engagement }\end{array}$} & 269 & Post-Survey & 3.52 & 1.24 & 0.08 \\
\hline & & Pre-Survey & 2.55 & 1.31 & 0.08 \\
\hline \multirow{2}{*}{$\begin{array}{l}\text { Teacher efficacy in } \\
\text { instructional strategies }\end{array}$} & 269 & Post-Survey & 3.66 & 1.24 & 0.08 \\
\hline & & Pre-Survey & 2.52 & 1.30 & 0.08 \\
\hline \multirow{4}{*}{$\begin{array}{l}\text { Teacher efficacy in } \\
\text { classroom management } \\
\text { Total for knowledge of } \\
\text { modern technologies }\end{array}$} & 269 & Post-Survey & 3.34 & 1.22 & 0.07 \\
\hline & & Pre-Survey & 2.46 & 1.31 & 0.08 \\
\hline & 269 & Post-Survey & 3.51 & 1.22 & 0.07 \\
\hline & & Pre-Survey & 2.51 & 1.30 & 0.08 \\
\hline
\end{tabular}

Source: own elaboration.

Table 1 shows the summary of the lecturers' post- and pre-survey of the TSES that assessed their level of knowledge of modern technologies for improving their self-efficacy in teaching in the areas of ESE, EIS, and ECM. The results show a total mean and standard deviation of 3.51 and 1.22 of the lecturers' responses in the post-survey. And in the pre-survey, their mean and standard deviation score is 2.51 and 1.30 respectively. The table shows a mean difference of 1.00. However, the researchers could not ascertain from the table whether the observed mean difference is statistically significant or could be attributed to a sampling error. The result was subsequently subjected to a paired sample t-test as shown in table 2 to test hypothesis 1 . The lower standard deviation of 1.22 for the lecturers' responses in the post-survey indicates that the lecturers' responses were clustered around the mean in the post-survey more than their responses in the pre-survey with a standard deviation of 1.30 . 
Table 2: Data Process of Paired Sample t-test on Post- and Pre-survey of Lecturers' Level of Knowledge of Modern Technologies

\begin{tabular}{|c|c|c|c|c|c|c|c|c|c|}
\hline & & & Pair & d Differ & nces & & & & \\
\hline & & & & & $95 \% \mathrm{Cc}$ & fidence & & & \\
\hline & & & & Std. & $\begin{array}{r}\text { Interv } \\
\text { Diff }\end{array}$ & $\begin{array}{l}\text { of the } \\
\text { ence }\end{array}$ & & & \\
\hline & & Mean & Deviation & Mean & Lower & Upper & $\mathrm{T}$ & Df & tailed) \\
\hline Pair 1. & $\begin{array}{l}\text { Post-TPDP - } \\
\text { Pre-TPDP }\end{array}$ & 0.99 & 0.53 & 0.03 & 0.93 & 1.06 & 30.96 & 268 & 0.00 \\
\hline
\end{tabular}

Source: own elaboration.

Table 2 is the data process result of a paired samples t-test that tested the null hypothesis1 (there is no significant impact of PDP on the science lecturers' level of knowledge of modern technologies for improving self-efficacy in teaching in the universities). From the table, the t-value is 30.96 and the sig. or p-value is 0.00 which is less than 0.05 set for the study. Also, the confidence interval of the difference was from 0.93 (lower bound) to 1.06 (the upper bound). Based on these results, the null hypothesis 1 is, therefore, rejected. This implies that there is a significant impact of the PDP on the lecturers' level of knowledge of modern technologies in teaching after completing the program $\left(\mathrm{t}{ }_{(268)}=30.96, p=0.00<\right.$ $0.05)$. The results have shown that the observed difference in the mean responses of the lecturers presented in table 1 is statistically significant, and the PDP is effective in enhancing the lecturers' level of knowledge of modern technologies and improve their self-efficacy in teaching in the areas of SE, IS, and CM in the universities.

The second research question was on the impact of PDP on the science lecturers' extent of use of modern technologies for improving their self-efficacy in teaching in the universities.

Table 3: Summary of Mean and Standard deviation of Lecturers' Pre- and PostSurveys of Extent of Use of Modern Technologies

\begin{tabular}{|c|c|c|c|c|c|}
\hline \begin{tabular}{l}
\multicolumn{1}{c}{ Item } \\
Utilization of modern \\
Technologies
\end{tabular} & $\mathrm{N}$ & Group & Mean & $\begin{array}{c}\text { Std. } \\
\text { Deviation }\end{array}$ & $\begin{array}{l}\text { Std. } \\
\text { Error } \\
\text { Mean }\end{array}$ \\
\hline Teacher efficacy in students' & 269 & Post-Survey & 3.20 & 1.24 & 0.08 \\
\hline engagement & & Pre-Survey & 2.64 & 1.32 & 0.08 \\
\hline Teacher efficacy & 269 & Post-Survey & 3.33 & 1.27 & 0.08 \\
\hline instructional strategies & & Pre-Survey & 2.54 & 1.32 & 0.08 \\
\hline Teacher efficacy in classroom & 269 & Post-Survey & 3.12 & 1.27 & 0.08 \\
\hline management & & Pre-Survey & 2.55 & 1.31 & 0.08 \\
\hline Total for utilization & 269 & Post-Survey & 3.22 & 1.25 & 0.07 \\
\hline modern technologies & & Pre-Survey & 2.58 & 1.31 & 0.08 \\
\hline
\end{tabular}

Table 3 shows that the total mean and standard deviation of the lecturers in the post-survey are 3.22 and 1.25 respectively, while in the pre-survey the mean and standard deviation scores are 2.58 and 1.31 respectively. The table shows a mean difference of 0.64 . However, the researchers could not deduce from the table 
whether the observed mean difference is statistically significant or could be attributed to a sampling error. Hence, the corresponding hypothesis 2 was tested using a paired sample t-test shown in table 4. Meanwhile, the lower standard deviation of 1.25 obtained in the post-survey responses shows that the lecturers' responses were clustered around the mean, while the higher standard deviation of 1.31 in the pre-survey shows more diversity in their responses.

Table 4: Paired Sample t-test on Post- and Pre-survey of Lecturers' Extent of Use of Modern Technologies

\begin{tabular}{|c|c|c|c|c|c|c|c|c|c|}
\hline & & & Pair & Diffe & hes & & & & \\
\hline & & & & & $95 \% \mathrm{C}$ & fidence & & & \\
\hline & & & & $\begin{array}{l}\text { Std. } \\
\text { Error }\end{array}$ & $\begin{array}{r}\text { Interv } \\
\text { Diff }\end{array}$ & $\begin{array}{l}\text { of the } \\
\text { ence }\end{array}$ & & & \\
\hline & & Mean & Deviation & Mean & Lower & Upper & $\mathrm{T}$ & Df & tailed) \\
\hline $\begin{array}{l}\text { Pair } \\
1 .\end{array}$ & $\begin{array}{l}\text { Post-TPDP - } \\
\text { Pre-TPDP }\end{array}$ & 0.64 & 0.37 & 0.02 & 0.60 & 0.69 & 28.51 & 268 & 0.00 \\
\hline
\end{tabular}

Source: Authors' elaboration.

Table 4 shows that the null hypothesis 3 (there is no significant impact of PDP on the science lecturers' extent of use of modern technologies for improving their self-efficacy) is rejected. The table shows a t-value of 28.51 and a sig. or p-value of 0.00 which was less than 0.05 set for the study. Besides, the confidence interval of the difference was from 0.60 as lower bound to 0.69 as the upper bound, hence the rejection of the null hypothesis 2 . The implication is that there is a significant impact of the PDP on the extent to which the lecturers use modern technologies for improving their self-efficacy after completing the program $\left(\mathrm{t}_{(268)}=28.51, p=0.00<0.05\right)$. The result shows that the observed mean difference in table 3 is statistically significant and that the PDP may have enhanced the extent to which the lecturers use modern technologies for improving their self-efficacy in teaching in the areas of SE, IS, and CM in the universities.

The third research question assessed the difference in the science lecturers' overall level of knowledge and extent of use of modern technologies in improving their self-efficacy in teaching in the universities after completing the PDP.

Table 5: Summary of Mean and Sd of Lecturers' Post-survey on knowledge and Use of Modern Technologies

\begin{tabular}{lcccc}
\hline \multicolumn{1}{c}{ Description } & $\mathrm{N}$ & Mean & $\begin{array}{c}\text { Std. } \\
\text { Deviation }\end{array}$ & $\begin{array}{c}\text { Std. Error } \\
\text { Mean }\end{array}$ \\
\hline $\begin{array}{l}\text { The overall level of Knowledge of modern } \\
\text { technologies }\end{array}$ & 269 & 3.51 & 1.22 & 0.07 \\
$\begin{array}{l}\text { The overall extent of use of modern } \\
\text { technologies }\end{array}$ & 269 & 3.22 & 1.25 & 0.08 \\
\hline
\end{tabular}

Source: Authors' elaboration.

Table 5 shows the overall mean and standard deviation of the science lecturers' level of knowledge of modern technologies in the post-survey are 3.51 and 1.22 respectively. Similarly, their overall mean and standard deviation scores on the 
extent of use of modern technologies in the post-survey are 3.22 and 1.252 respectively. The table shows a mean difference of 0.29 . However, the researchers could not establish from the table whether the observed mean difference is statistically significant or could be a result of sampling error. Therefore, the result is subjected to a paired sample t-test to test the null hypothesis 3 shown in table 6. The standard deviations of 1.22 and 1.25 show that the lecturers' responses on knowledge of modern technologies were clustered around the mean more than their responses on the extent of use of modern technologies, which showed more diversity.

Table 6: Paired sample t-test on the overall Lecturers' Level of Knowledge and Extent of Utilisation of Modern Technologies

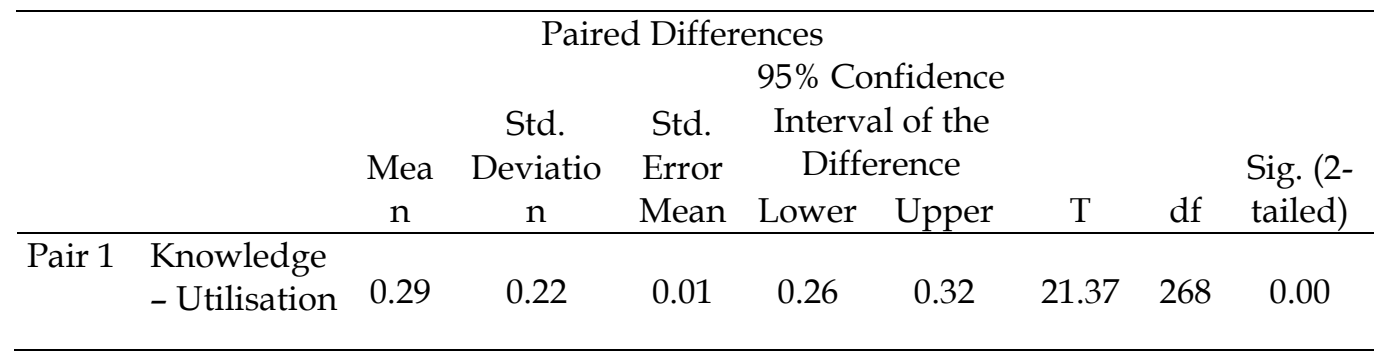

Source: Authors' elaboration.

Table 6 shows that the null hypothesis 3 (there is no significant difference in the science lecturers' overall level of knowledge and extent of use of modern technologies for improving their self-efficacy in teaching after completing the PDP) is rejected. The table shows a $t$-value of 21.37 and sig. (2-tailed) or p-value of 0.00 less than 0.05 set for the study. The confidence interval of the difference was from 0.26 (lower bound) to 0.32 (upper bound) hence, the rejection of the null hypothesis 3 . The result implies a statistically significant difference between the science lecturers' overall level of knowledge and the extent of use of modern technologies for improving their self-efficacy in teaching after completing the PDP $(\mathrm{t}(268)=21.37, p=0.00<0.05)$. Therefore, the observed mean difference in table 5 is statistically significant. The implication is that the PDP may have enhanced the lecturers' level of knowledge more than the extent to which they use modern technologies for improving their self-efficacy in teaching in the areas of SE, IS, and CM in the universities.

\section{Discussion of Findings}

The findings of this study have shown that the professional development program (PDP) might have enhanced the knowledge of the lecturers in modern technologies for improving their self-efficacy in teaching in the areas of students' engagement, use of diverse instructional strategies, and classroom management techniques in the universities. The above assertion arrived because the mean difference observed in the pre-survey and post-survey responses of the lecturers were statistically significant. The finding agrees with Voogt et al. (2005), Lavonen et al. (2006), Giordano (2008), and Udu (2020) who found separately that professional development programs have the capacity of enhancing participants' knowledge and attitude towards the use of technologies for 
instructional purposes. This study has, therefore, demonstrated that PDP has the capacity for effectively enhancing the lecturers' knowledge of modern technologies for improving their self-efficacy in teaching, specifically, in engaging the students actively in the teaching and learning processes.

Furthermore, from the findings, it was revealed that the lecturers' use of modern technologies in teaching generally increased after completing the professional development program (ADAPTI). This assertion was made on the basis that the lecturers' overall mean responses on the extent of use of modern technologies in teaching in the post-survey responses were greater than their mean responses in the pre-survey and that the mean difference recorded was statistically significant. The finding is consistent with Lavonen et al. (2006) and Giordano (2008) who found that, after completing a professional development program, the participants' extent of utilization of technologies for instructional purposes was greatly improved. In line with Lavonen et al. and Giordano's observations, this present study recorded a similar general significant improvement on the lecturers' extent of use of modern technologies in teaching for improving their self-efficacy after completing the PDP.

Similarly, this study has found that the lecturers' level of knowledge of modern technologies after completing the PDP was greater than the extent to which they use modern technologies in the teaching and learning processes. This finding agrees with Brinkerhoff (2006), Fragkouli and Hammond (2007), and Glazer et al. (2009) that although professional development programs increase the participants' acquisition of technology skills, the extent of use of such skills are still very low and had very limited impact on classroom practice. The study also established that the lecturers' self-efficacy in students' engagement, use of instructional strategies, and classroom management was high. This agrees with Tschannen-Moran and Hoy (2001) and Udu (2020) that professional development programs enhance professional proficiency and self-efficacy in the teaching and learning processes. The researchers observed from the findings of this study that the lecturers still experience some challenges in the use of modern technologies in the teaching and learning processes in their classrooms. Efforts were made by the researchers to determine the reasons for the low level of use of modern technologies, after the completion of a training program by the lecturers, showed that many factors were responsible. Some of the responsible factors they listed include; non-availability of modern technologies, specifically computers; erratic power supply; lack of internet access in the schools; high cost of internet connectivity, etc. It was observed that the presence of most of these factors in the universities is seriously hampering the effective utilization of modern technologies in the teaching and learning processes in most tertiary institutions in the developing countries, including Nigeria (Ayoub, Petra \& Joke, 2016).

\section{The Implication for Sustainable Science Education in the Developing Nations}

Somayyeh et al. (2018) identified education generally and science education in particular as a key factor in human development. This is because science 
education is very vital in the scientific and technological development of any nation (Udu, 2018). It has been observed that recent global changes in society, in the areas of the economy, and politics may harm education. To checkmate, these global changes require effective science and technological education in the universities. Besides, Mohammad and Khaled (2017) indicated that the changing roles of educators as a result of the global changes and expectations of the society require constant training and retraining to improve their quality. The training can be achieved through regular organization and participation in professional development programs. Moreover, regular engagement of the science lecturers to PDP has been found to enhance their capacity to achieve effective teaching and improve their self-efficacy, which may lead to sustainable science education, especially in developing nations such as Nigeria. Sustainable science education is seen in this study as the science lecturers' acquisition of fundamental knowledge, skills, and positive attitudes in the use of technologies for effective teaching and learning processes in science education.

Furthermore, previous studies that highlighted the benefits of professional development programs emphasized that PDP enhances the participants' ability to learn and develop the knowledge and essential skills required for good professional practices with technologies, for a sustainable education system (UNESCO, 2005; Buczynski \& Hansen, 2010; Gabriel et al., 2011; Besong \& Holland, 2015).

Consequently, Knapp (2003) reiterated that professional development programs are vital links to improving the effectiveness of the participants. Therefore, science lecturers should be encouraged to regularly attend PDPs for opportunities to update their professional knowledge and skills, especially in modern technologies, to help in improving their self-efficacy in science teaching and learning for sustainable science education in developing nations.

\section{Conclusion and Recommendations}

This study has shown that professional development programs (PDPs) can help to enhance science lecturers' knowledge and use of modern technologies for improving their self-efficacy in teaching in the areas of students' engagement, instructional strategies, and classroom management in the universities in a developing nation, Nigeria. The finding emphasizes that when lecturers have acquired the knowledge and make effective use of modern technologies, they can apply such knowledge and skills in their teaching processes. This would help to enhance the lecturers teaching effectiveness, and subsequently, result in engaging the students actively in the classrooms, as well as motivating them for effective learning. The lecturers should, therefore, strive to attend professional development programs to acquire skills for incorporating the use of modern technologies into their daily teaching processes in their classrooms. The science lecturers, as well as other lecturers in the universities, should note that teaching with technologies is not only about keeping up to date with all the latest modern teaching tools available, but it involves effective utilization of the technologies in the teaching and learning processes. The science lecturers and others should be encouraged by the university management and other higher education 
stakeholders to regularly engage in PDPs for improving their self-efficacy in teaching for sustainable science education. The management of tertiary institutions should establish a feedback mechanism for regular monitoring of lecturers that have participated in PDPs for proper and regular application of the knowledge of technologies acquired during the training. Finally, the lecturers should be assisted to procure technological gadgets, internet access, constant power supply, etc. to enhance their effectiveness in the use of modern technologies in science teaching for improving their self-efficacy and sustainable science education.

\section{Limitations of the study}

The researchers could not sample all the lecturers that participated in the professional development program due to logistics reasons. This might affect the generalization of the results of this study.

\section{Conflict of Interest Statement}

The authors have no conflict of interest to declare.

\section{References}

Ayoub, K., Petra, F., \& Joke V. (2016). Factors affecting teachers' continuation of technology use in teaching. Education and Information Technology, 21(6), 15351554. doi:10.1007/s10639-015-9398-0

Barni, D., Danioni, F., \& Benevene, P. (2019). Teachers' Self-Efficacy: The Role of Personal Values and Motivations for Teaching. Frontiers in Psychology, 10, 1645. doi:10.3389/fpsyg.2019.01645

Besong, F., \& Holland, C. (2015). The dispositions, abilities, and behaviors (DAB) framework for profiling learners' sustainability competencies in higher education. Journal of Teacher Education for Sustainability, 17(1), 5-22. doi:10.1515/jtes-2015-0001

Brinkerhoff, J. (2006). Effects of a long-duration, professional development academy on technology skills, computer self-efficacy, and technology integration beliefs and practices. International Society for Technology in Education, 39(1), 22-43. doi:10.1080/15391523.2006.10782471

Buczynski, S., \& Hansen, C. B. (2010). Impact of professional development on teacher practices: Uncovering connections. Teaching and Teacher Education, 26(3), 599-607. doi:10.1016/j.tate.2009.09.006

Caprara, G. V., Barbaranelli, C., Steca, P., \& Malone, P. S. (2006). Teachers' self-efficacy beliefs as determinants of job satisfaction and students' academic achievement: A study at the school level. Journal of School Psychology, 44(6), 473-490. doi:10.1016/j.jsp.2006.09.001

Chen, C. H. (2008). Why do teachers not practice what they believe regarding technology integration? The Journal of Educational Research, 102(1), 65-75. doi:10.3200/JOER.102.1.65-75

Chong, W. H., Klassen, R. M., Huan, V. S., Wong, I., \& Kates, A. D. (2010). The relationships among school types, teacher efficacy beliefs, and academic climate: Perspective from Asian middle school. Journal of Educational Research, 103(3), 183190. doi:10.1080/00220670903382954

Davies, R., Sprague, C., \& New, C. (2008). Integrating technology into a science classroom: An evaluation of inquiry-based technology integration. In D. W. Sunal, E. L. Wright, \& C. Sundberg (Eds.), The impact of technology and the 
laboratory on K-16 science learning series: Research in science education (pp. 207-237). Information Age Publishing.

Digital Bridge Institute, DBI. (2018). Advanced digital appreciation program for tertiary institutions (ADAPTI). Nigerian Communications Commission.

Djigic, G., Stojiljkovic, S., \& Doskovic, M. (2014). Basic personality dimensions and teachers' self-efficacy. Procedia-Social and Behavioural Sciences, 112, 593-602. doi:10.1016/j.sbspro.2014.01.1206

Fragkouli, E., \& Hammond, M. (2007). Issues in developing programs to support teachers of philology in using information and communications technologies in Greek schools: A case study. Journal of In-Service Education, 33(4), 463-477. doi:10.1080/13674580701687849

Fullan, M. (2015). The new meaning of educational change (5 ${ }^{\text {th }}$ Ed). New York: Teachers College Press.

Gabriel, R., Day, J. P., \& Allington, R. (2011). Exemplary teacher voices on their development. Phi Delta Kappan, 92(8), 37-41. doi:10.1177/003172171109200808

Glazer, E. M., Hannafin, M. J., Polly, D., \& Rich, P. (2009). Factors and interactions influencing technology integration during situated professional development in an elementary school. Computers in the Schools, 26(1), 21-39. doi:10.1080/07380560802688257

Giordano, V. A. (2008). A professional development model to promote internet integration into p-12 teachers' practice: A mixed-methods study. Computers in the Schools, 24(3), 111-123. doi:10.1300/J025v24n03_08

Goktaş, Y., Yildirim, Z. \& Yildirim, S. (2008). A review of ICT-related courses in preservice teacher education programs. Asia Pacific Education Review. 9(2), 168-179. doi:10.1007/BF03026497

Hennessy, S., Ruthven, K., \& Brindley, S. (2005). Teacher perspectives on integrating ICT into subject teaching: commitment, constraints, caution, and change. Journal of Curriculum Studies, 37(2), 155-192. doi:10.1080/0022027032000276961

Ho, I. T., \& Hau, K. T. (2004). Australian and Chinese teacher efficacy: Similarities and differences in personal instruction, discipline, guidance efficacy and beliefs in external determinants. Teaching and Teacher Education, 20(3), 313-323. doi:10.1016/j.tate.2003.09.009

Karehka, R. (2013). The use of technology - in education and the teaching process. https:// www.useoftechnology.com/the-use-of-technology-in-education/

Kennedy, A. (2005). Models of Continuing Professional Development: A Framework for Analysis. Journal of In-service Education, 31(2), 235-250. doi:10.1080/13674580500200277

Klassen, R. M., \& Tze, V. M. C. (2014). Teachers' self-efficacy, personality, and teaching effectiveness: A meta-analysis. Educational Research Review, 12, 59-76. doi:10.1016/j.edurev.2014.06.001

Knapp, M. S. (2003). Professional development as a policy pathway. Review of Research in Education, 27(1), 109-157. doi:10.3102/0091732X027001109

Lavonen, J., Juuti, K., Aksela, M., \& Meisalo, V. (2006). A professional development project for improving the use of information and communication technologies in science teaching. Technology, Pedagogy, and Education, 15(2), 159-174. doi:10.1080/14759390600769144

Lau, S., Liem, A. D., \& Nie, Y. (2008). Task and self-related pathways to deep learning: The mediating role of achievement goals, classroom attentiveness, and group participation. British Journal of Educational Psychology, 78(4), 639-662. doi:10.1348/000709907×270261 
Liu, S.-H. (2012). Teacher professional development for technology integration in a primary school learning community. Technology, Pedagogy, and Education, 22(1), 37-54. doi:10.1080/1475939x.2012.719398

Lynch, M. (2017). Seven (7) ways technology is impacting modern education. https:// www.thetechedvocate.org/7-ways-technology-impactingmodern-education/

Marshall, S. (2010). Change, technology, and higher education: Are universities capable of organizational change? ALT-J: Research in Learning Technology. 18(3), 179192. doi:10.1080/09687769.2010.529107

McCarney, J. (2004). Effective models of staff development in ICT. European Journal of Teacher Education, 27(1), 61-72. doi:10.1080/0261976042000211801

Moe, A., Pazzaglia, F., \& Ronconi, L. (2010). When being able is not enough: The combined value of positive affect and self-efficacy for job satisfaction in teaching. Teaching and Teacher Education, 26(5), 1145-1153. doi:10.1016/j. tate.2010.02.010

Mohammad, M., \& Khaled, M. (2017). Exploring change in EFL teachers' perceptions of professional development. Journal of Teacher Education for Sustainability, 19(1), 22 42. doi:10.1515/jtes-2017-0002

Organization for Economic Cooperation and Development, OECD. (2009). Creating effective teaching and learning environments: First results from TALIS. https:// www.oecd.org/berlin/43541636.pdf

Padwad, A., \& Dixit, K. (2011). Continuing professional development: An annotated bibliography. Delhi: British Council. http://www.teachingenglish.org.uk/sites/teacheng/files/CPDbiblio.pdf

Somayyeh, G., Seyed, E. M. J., \& Fereydoon, S. (2018). Learning to Be: Teachers' competencies and practical solutions: A step towards sustainable development. Journal of Teacher Education for Sustainability, 20(1), 20-45. doi:10.2478/jtes-20180002

Sousa, C. M. P., Coelho, F., \& Guillamon-Saorin, E. (2012). Personal values, autonomy, and self-efficacy: evidence from frontline service employees. International Journal of Selection and Assessment, 20(2), 159-170. doi:10.1111/j.1468-2389.2012.00589.x

Speck, M., \& Knipe, C. (2005). Why can't we get it right? Designing high-quality professional development for standards-based schools (2nd ed.). Thousand Oaks: Corwin Press.

Tareq, M. (2020). Efficacy of teachers' in-service training for increasing their Knowledge of attention deficit hyperactivity disorder in Eastern Region, Saudi Arabia. International Journal of Learning, Teaching and Educational Research, 19(12), 295-312. doi:10.26803/ijlter.19.12.16

Tschannen-Moran, M., \& Hoy, A. W. (2001). Teacher efficacy: Capturing an elusive construct. Teaching and Teacher Education, 17(7), 783-805. doi:10.1016/S0742051X(01)00036-1

Udu, D. A. (2018). Innovative practices in science education: A panacea for improving secondary school student's academic achievement in science subjects in Nigeria. Global Journal of Educational Research, 17(1), 23 - 30. doi:10.4314/gjedr.v17i1.4

Udu, D. A. (2020). Impact of teacher professional development programs on science lecturers' knowledge and use of modern technologies in teaching in tertiary institutions. Journal of the Nigerian Academy of Education, 16(1), 111-128.

UNESCO. (2005). Guidelines and recommendations for reorienting teacher education to address sustainability. Education for Sustainable Development in Action Technical Paper No. 2, UNESCO Education sector.

US Department of Education. (2011). Use of technology in teaching and learning. https://www.ed.gov/oii-news/use-technology-teaching-and-learning 
Usher, E. L., \& Pajares, F. (2008). Sources of self-efficacy in school: Critical review of the literature and future directions. Review of Educational Research, 78(4), 751- 796. doi:10.3102/0034654308321456

Voogt, J., Almekinders, M., van den Akker, J., \& Moonen, B. (2005). A 'blended' inservice arrangement for classroom technology integration: Impacts on teachers and students. Computers in Human Behaviour, 21(3), 523-539. doi:10.1016/j.chb.2004.10.003

Whitcomb, J., Borko, H., \& Liston, D. (2009). Growing talent: Promising professional development models and practices. Journal of Teacher Education, 60(3), 207-212. doi:10.1177/0022487109337280

Yoo, J. H. (2016). The effect of professional development on teacher efficacy and teachers' self-analysis of their efficacy change. Journal of Teacher Education for Sustainability, 18(1), 84-94. doi:10.1515/jtes-2016-0007 
Appendix 1: Lecturers' Self-Efficacy Scale on Knowledge and Use of Modern Technologies

\section{Section A: Personal/Bio-data}

i. Name of Institution:

ii. Department:

iii. Rank:

iv. Age:

v. Length/Number of Years of Teaching:

vi. Gender: Male $\square$ Female $\square$ Others $\square$

\section{Section B: Questionnaire items on Knowledge and Use of Modern Technologies in Teaching}

Instruction: Tick $\square$ in the option that best describes your opinion on the level of knowledge and extent of utilization of modern technologies, using the following keys; Very Large Extent $(\mathrm{VLE})=5$, Large Extent $(\mathrm{LE})=4$, Moderate Extent $(\mathrm{ME})=3$, Small Extent $(\mathrm{SE})=2$, Very Small Extent (VSE) $=1$.

\begin{tabular}{|c|c|c|c|c|c|c|}
\hline \multicolumn{7}{|c|}{ Part 1: Lecturers' Knowledge of Modern Technologies in Teaching } \\
\hline SN & Item & VLE & LE & ME & SE & VSE \\
\hline \multicolumn{7}{|c|}{ Knowledge of Modern Technologies for Efficacy in Students' Engagement (KESE) } \\
\hline 1 & $\begin{array}{l}\text { To what extent can your knowledge of modern } \\
\text { technologies help you to motivate students who } \\
\text { show low interest in school work? }\end{array}$ & & & & & \\
\hline 2. & $\begin{array}{l}\text { To what extent can your knowledge of modern } \\
\text { technologies help you to revive students' interest } \\
\text { and believe that they can do better in schoolwork? }\end{array}$ & & & & & \\
\hline 3. & $\begin{array}{l}\text { To what extent can your knowledge of modern } \\
\text { technologies enable you to help your students to } \\
\text { value learning? }\end{array}$ & & & & & \\
\hline 4. & $\begin{array}{l}\text { To what extent can your knowledge of modern } \\
\text { technologies enable you to assist families in helping } \\
\text { their children to do well in school? }\end{array}$ & & & & & \\
\hline \multicolumn{7}{|c|}{ Knowledge of Modern Technologies for Efficacy in Instructional Strategies (KEIS) } \\
\hline 5. & $\begin{array}{l}\text { To what extent can your knowledge of modern } \\
\text { technologies assist you to craft good questions for } \\
\text { your students? }\end{array}$ & & & & & \\
\hline 6. & $\begin{array}{l}\text { To what extent can your knowledge of modern } \\
\text { technologies enable you to use varieties of } \\
\text { assessment strategies? }\end{array}$ & & & & & \\
\hline 7. & $\begin{array}{l}\text { To what extent can your knowledge of modern } \\
\text { technologies assist you to provide alternative } \\
\text { explanations, or examples when students are } \\
\text { confused? }\end{array}$ & & & & & \\
\hline 8 & $\begin{array}{l}\text { To what extent can your knowledge of modern } \\
\text { technologies help you to implement alternative } \\
\text { instructional strategies in your classroom? }\end{array}$ & & & & & \\
\hline
\end{tabular}




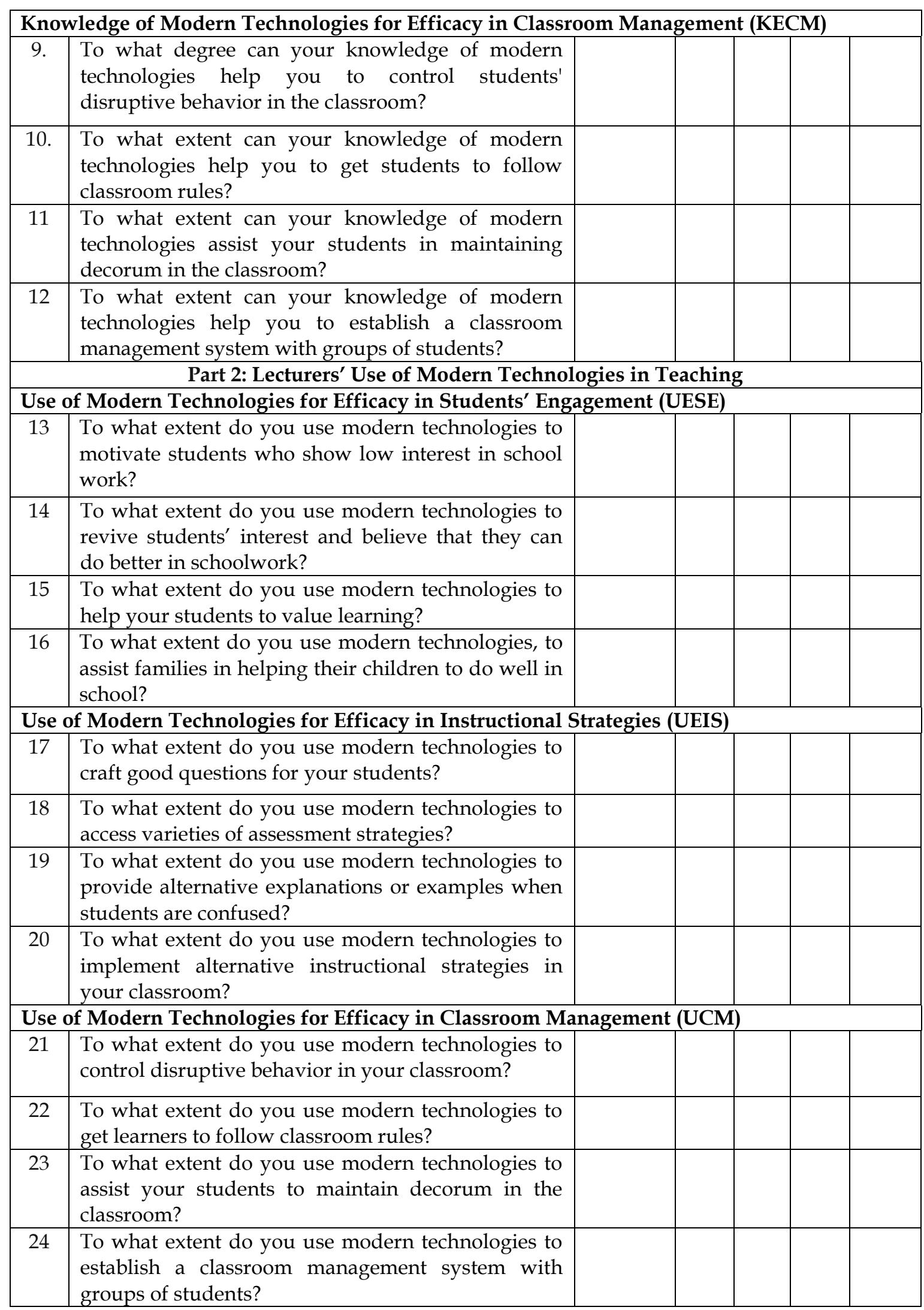

